\title{
College Students' Perceived Brand Value in Service and Manufacturing Categories
}

\author{
Yuexuan Gong ${ }^{*}$ and Pengzhi XU ${ }^{2}$ \\ ${ }^{1}$ Research Institute of Economics and Management, Southwestern University of Finance and Economics, China \\ ${ }^{2}$ School of Economics, Shanghai University, China
}

Submission: July 07, 2019; Published: August 21, 2019

"Corresponding author: Yuexuan Gong, Research Institute of Economics and Management, Southwestern University of Finance and Economics, China

\begin{abstract}
We study college students' perceived brand value in service and manufacturing categories by structural equation model (SEM) in information economics perspective, based on the investigation of successful multinational companies (MNCs)' brands, take brand as a signal and analyze the differences of the brand value between service and manufacturing categories for their different degrees of information asymmetry. Our definition of brand value is the value of a brand as a signal to consumers (We narrow the group to college students in this paper). Our study gets some preliminary results: Only brand investment on the formation of brand consistency can it really exert effective influence to upgrade brand credibility. Consistency is more important to service category in promoting brand credibility for its higher information asymmetry. Credible brand (brand as a signal) can save information cost and elevate perceived quality of commodity or service. Moreover, it enables to increase brand value (or utility) by two paths, one is by perceived quality; another is information cost saved. The former plays a more important role in advancing brand value in manufacturing category, and the later performs better in-service category. Finally, managerial advice is also proposed.
\end{abstract}

Keywords: Information Asymmetry; Brand signal; Brand value

\section{Introduction}

Global top MNCs are armed with strong financial strength, complete decision-making system, global uniform strategies and global influence. Most of the invaluable brands are coming from famous MNCs. And at present, pursuing famous brands is all the rage in universities in China. When many undergraduates and graduates purchase the products and service they need in their daily life, they prefer to famous brands, because they reckon that established brands indicate good quality, experience and less risks. This streamlines their process of decision-making when facing numerous varieties of goods and services in a market full of information asymmetry. In this process, brands are taken as signals of the quality of goods and services by students in an asymmetrical information market. Thus, it is important for firms to know how a credible brand is shaped and how brand as a credible signal shapes brand value in two different categories (service and manufacturing). It is supposed that there must be some differences in the process of the formation of brand value for their different degree of information asymmetry.

\section{Brand as A Signal}

\section{A Market with Information Asymmetry and its Reason and Derived Solution.}

Since Akerlof [1] wrote his famous paper the Market for "lemons": Quality Uncertainty and the Market Mechanism, published in Quarterly Journal of Economics in 1970, the problem of information asymmetry has stepped into the spotlight of economic studies, He said that "there are no mutual credit between people, because people's mind and brains are not connected, high quality products distinguishing themselves from low quality products requires substantial costs", so the existence of information asymmetry may perhaps lead to the failure of market. The classical economic theory which assumes perfect and complete information fails to reveal the truth of reality.

The reasons are as follows: uncertainty and "knowledge" is dispersed in everyone' mind. We make choices under uncertainty all the time. Uncertainty arises at least two sources: imperfect foresight and human inability to solve complex problems containing a host of variables Armen A. Alchian [2] and many variables are invisible for people, so the secondary choose for people is to use something observable to substitute unobservable. For example, why exist race discrimination? Race discrimination is a kind of statistical discrimination. This is due to some causes, perhaps quality of education, perhaps cultural differences; but the cause is not itself observable. Based on their experience, people use the observable characteristics-race, to judge their abilities or characters. Arrow [3]. Normally, consumers adopt observable variables, such as price, advertising, warranty as signals to speculate information of the attributes of products and services. 


\section{Price as a Solution and its Limitation}

The most common signal human beings use---price. FA Hayek [4] said price is a perfect solution to solve information (in his paper named knowledge) problems. Because price can convey information efficiently and economically (1974). But if market can aggregate information perfectly, and finally form an effective price, individuals will have no incentives to acquire information. So how would it possible for market to aggregate information perfectly? Grossman and Stiglitz [5,6]. Actually, Hayek just emphasize the scarcity of knowledge, except that there are many dimensions to knowledge and information beyond scarcity---knowledge about the components of new products, information about individual's abilities and performance. Stiglitz explained that Hayek did not try to model how the economy processed information. Until the development of information economics, models in which economic systems had to adjust to new information we not formulated Stiglitz [7]. Moreover, price can be manipulated deliberately or forged in short term. High price does not necessarily represent good quality in a market with information asymmetry to some extent.

\section{Other Ways and Why is Brand}

Information that is relevant to economic actors is conveyed not just by prices, but by a host of other variables, including actions, behavior, quantities, marks Stiglitz [7] Advertising is an example. Companies will invite stars to endorse their products and spent quite a lot of money on advertising. This money spent is sunk cost, which hints that fly-by-night firms are not likely to afford high price, reflecting their determination to offer high quality goods and services.

The above ways work normally but fail accidently. Because signals are credible only if sellers do not find it profitable to "cheat" by conveying false market signals [8]. In fact, those signals may not be credible because they are subject to adverse selection or moral hazard problems $[9,10]$. For example, when sellers find it profitable to cheat, in order to get a short-term profit, low-quality sellers may imitate high-quality sellers' behavior to confuse and deceive consumers, which results in the failure of signals. Just like a "one-shot" game. So, the limitation of individual marketing mix elements as a credible signal provides the motivation for the examining the role that brands may play in markets with asymmetric and imperfect information [8]. Brand is more like a kind of "repeated game", without long-term efforts and credible behavior, a brand cannot be trusted by consumers.

Brand is a comprehensive reflection of many visible and invisible parts of a firm, including investment, history, scale, quality, marketing strategies and so on, so do not be fooled into thinking it is just a product's name. A brand understood to be "a name, term, sign, symbol, or design, or a combination of them, that is intended to identify the goods and services of one seller or a group of sellers and to differentiate them from those of competitors Kotler (1997). Brand signals much information. Erdem and Swait $[8,11,12]$ wrote a series of papers about brand as a signaling phenomenon $(1998,2006,2007)$ In their views, "consumer-based brand equity is defined as the value of a brand signal to consumers. A brand becomes a signal because it embodies a firm's past and present marketing strategies (1998). Thus, with asymmetric and imperfect information, brands may be more reliable, and more stable, served as market signals, than abovementioned strategies."

Brand has long been recognized as a signal Joffre Swait [8], Wemerfelt [10], Rao [13], E Calderon Monge, P Huerta Zavala [14], Strizhakova, Coulter and Price [15], Nelissen and Meijers [16], Rahman, Serrano and Lambki [17]. We further develop brands in signaling perspective but focus on the comparison between manufacturing and services.

\section{Manufacturing and Service Categories}

Manufactured goods and services own different natures, which, we suppose, may influence the functional mechanism of brand as a signal. Most manufacturing firms have their main products, consumers can know them by their tangible components. However, most service firms are not. Service lacks substantiality. Fuchs (1968). Service disappears now of its production. It can be only supplied at the presence of consumers Hill (1977). It cannot be transported, accumulated or warehoused. It is concluded that there are four characteristics of service: Intangibility, Inseparability, Perishability, Heterogeneity. Those characteristics determine the difficulty that buyers face in evaluating the quality of services and therefore influence the extent of information asymmetry between buyers and sellers Nayyar [18].

However, this paper does not study the concrete industries, because service industry and manufacturing industry all conclude countless levels and classifications, which contains different degrees of information asymmetry. The concrete comparison of details between the two categories is not our paper's category and it is also unmeasurable. We just want to know how the consumers "feel" and perceive about the two categories generally, and how its impact on the process of formation of brand value. The definition of service category is that if a firm main business satisfying at least one of two criteria, namely, intangibility and dependence on a customer's participation or input in the service's production Boddewyn and Perry (1986), it belongs to service category. People perceive that service category has severer information asymmetry than manufacturing.

\section{Model}

The model sees (Figure 1) of this paper is developed from Erdem and Swait's [8] framework.

\section{The introduction of key concepts in the Model.}

\section{Credibility}

The asymmetrical information structure of the market motivates the role of credibility. Brand credibility (the credibility of a brand as a signal) is defined as the believability of the product 
position information contained in a brand, which requires that trustworthiness) to continuously deliver what has been promised the brand have the ability (i.e., expertise) and willingness (i.e., Swait and Erdem [12]. Credibility underlies the brand value.

Figure 1: A conceptual framework of brand value.

\section{Perceived quality}

We can divide qualities into three types: search qualities (color, style, price...) experience qualities (taste, purchase satisfaction, security, reliability...) credence qualities (the degree of service provider, professionalism and knowledge...). Aaker (1991) suggests that, all else being equal, strong brands are associated with higher perceived quality, which refers to mean beliefs about quality. Uncertainty about quality also implies that there is variance with consumer beliefs about quality for a given consumer. We should tell perceive quality and actual quality. Before the purchase behavior occurs, the customer obtains various information related to the product through various channels and has a preliminary understanding of the product to be selected. At this time the quality of the customer is dominated by the perceived quality, and to a certain extent it determines the customer's purchase line; after the purchase behavior, the actual quality of the product is in the dominant position, and the customer compares the actual quality with the perceived quality through the actual use of the product, and determines whether or not to buy a second time.

If there are static states, there may be 3 states:

a) Customer perceived quality > actual quality, the result is that customers are disappointed and the repetition of purchasing decreases.

b) Customer perceived quality =real quality, at this time, customers react normally, may continue to buy.

c) The perceived quality of customers $<$ the actual quality, this stimulates customers' desire to buy and increases their repetitiveness.

\section{Information cost}

Any goods can be defined as a collection of characteristics or features. For example, a coffee mug may possess the characteristics of cylindricality, heaviness, heat resistance, or any other such collection of features. Any characteristic can be defined and comprehended only at some cost. So, consumers need to take time and efforts to gain information relevant to their choses, which becomes a part of the real cost of the products or service they will buy.

\section{Empirical analysis}

\section{Data collection}

The data were obtained through questionnaires from undergraduate and graduate students mainly coming from universities in China. The students surveyed spread over 9 provinces in China [19]. The targeted students are in the similar environment, eliminating the disturbance of their fortune, education, status and the like to great extent. Finally, we get 58 complete and effective questionnaires.

We select 10 typical, successful brands of top MNCs, including manufacturing category [ P\&G(U.S.), Coca-Cola(U.S.), Apple(U.S.), Haier(China), Uniqlo(Japan)] and service category [Industrial and Commercial Bank of China, McDonald's(U.S.), Disney(U.S.), Time Warner(U.S.), Wal-Mart(U.S.)]. They come from ten different industries respectively: daily necessities, soft drinks, electronics, household appliances, clothing, banking, food, entertainment, movie and retail. There is a total of 580 individual observations for each item (290 for service brands and 290 for manufacturing brands).

We choose famous brands for the following reasons:

a) On the one hand, famous brands from top MNCs are more well-known to my respondents, and closer to our life. This is the precondition for respondents to answer questionnaire.

b) On the other hand, well-known brands are successful ones that have been credible signals. So, they can be used to study how the credible brands are formed and how they influence brand value in information economics perspective. 
There are 16 questions totally, dividing them to 6 sections. Brand investment has 2 questions, consistency has 3 questions, credibility 4 , perceived quality 2 , information cost saved 3 and expected utility (representing brand value) is 2 . We first test the reliability and validity. All indices are good. And then we test the overall fitness of the conceptual model (Table 1). The resulting indices for the overall sample (i.e., 2.893) is less than the cut-off point of 3 as suggested by Bagozzi \& Yi [9]. The model also has superior fit indices, specifically, NFI is equal to 0.904; CFI is equal to 0.935 , GFI is equal to 0.897 ; IFI is equal to 0.953 ; TLI is equal to 0.928 , and RMSEA if equal to 0.047 . Furthermore, we test the square root of AVE for all the sampled measures are greater than the correlations between constructs which indicates validity in discriminant (Table 2).

Table 1: SEM Fit indexes assessment.

\begin{tabular}{|c|c|c|c|c|c|c|c|c|}
\hline Index & GMIN/DF & GFI & PGFI & RMSER & IFI & NFI & TLI & CFI \\
\hline GOODNESS OF FIT(Standard) & $\leq 3$ & $\geq 0.9$ & $>0.5$ & $\leq 0.05$ & $\geq 0.9$ & $\geq 0.9$ & $\geq 0.9$ & $\geq 0.9$ \\
\hline Results & 2.893 & 0.897 & 0.701 & 0.047 & 0.953 & 0.904 & 0.928 & 0.935 \\
\hline
\end{tabular}

Table 2: Indicates that the path coefficient passes the test of significance 0.01 .

\begin{tabular}{|c|c|c|}
\hline Path & Manufacturing & Services \\
\hline Brand investment -> Credibility & 0.09 & 0.01 \\
\hline Consistency -> Credibility & $0.60^{* * *}$ & $0.73^{* * *}$ \\
\hline Credibility -> Perceived Quality & $0.86^{* * *}$ & $0.87^{* * *}$ \\
\hline Credibility -> Information Cost Saved & $0.69^{* * *}$ & $0.80^{* * *}$ \\
\hline Information Coat Saved -> Brand Value & $0.32^{* * *}$ & $0.44^{* * *}$ \\
\hline Perceived Quality -> Brand Value & $0.81^{* * *}$ & $0.73^{* * *}$ \\
\hline Credibility -> Information Cost Saved -> Brand \\
Value & $0.2208^{* * *}$ & $0.352^{* * *}$ \\
\hline Credibility -> Perceived Quality -> Brand Value & $0.6966^{* * *}$ & $0.6351^{* * *}$ \\
\hline
\end{tabular}

\section{The Anlysis of Results}

It is surprising that the path coefficient -Brand investment to Credibility is not statistically significant. But the path coefficient -Consistency to Credibility is 0.60 and 0.73 in manufacturing and service categories respectively. Those results confirm the abovementioned theoretical analysis of credibility. Consistency is the stable expectation and good reputation a company has created, like the chain shores, stable expectation of products or service (tastes, price, image, quality and so on) reduces the information asymmetry dramatically between consumers and sellers or producers, thus making the products they offer more reliable to consumers. The good quality, in information economics, is one which brings stable expectation of the quality of products or services for consumers [20-22].

This sheds a light on the design of marketing strategies. Because blindly brand investment hardly contributes to the cultivation of brand credibility, as the model shows. So, marketing such as advertisement should attach more importance to consistency. Only investment on the formation of brand consistency can it really exert effective influence to upgrade brand credibility [23]. This process needs communication between sellers and buyers. "Consumer's perceptions of a firm's brand investment depend on the firm's success in communicating its brand investment to consumers" Erdem and Swait [8]. Companies need to keep uniformity in their marketing campaigns, avoiding obvious discrepancies between advertisement promotion and actual products. This inconformity undermines brand credibility. Moreover, the path coefficient- Consistency to Credibility-of service brands 0.73 is bigger than manufacturing brands 0.6 , which illustrates that consistency is more important to service brands. Because the characteristics of services make it harder for consumers to collect relevant information, resulting in more severe information asymmetry [24].

Brand as a credible signal can compound brand value by two paths---Credibility-Perceived quality---Brand value(C-P-B) and Credibility-Information cost saved -Brand value(C-I-B) The former estimated path coefficients are 0.6966 and 0.6351 in manufacturing category and service category respectively. The later are 0.2208 and 0.352 . So firstly, the data shows that a credible brand influences brand value mainly by perceived quality of consumers and there is nearly no difference on this path between service and manufacturing category (for 0.6351 is very close to 0.6966). The reason maybe that, on the one hand, character of inseparability of the service can let consumers participate in the process of servicing. Consumers can experience it and estimate it continuously, this process reduces information asymmetry to large extent, such as hairdressing and that, on the other hand, products in manufacturing category are non-transparent $[25,26]$.

For example, most of us do not know what components are in a computer, let alone the qualities and functions of them. Even 
a bottle of mineral water we do not know exactly if it is really containing what it claims. So, there is maybe no big difference in the perceived quality aspect in both categories. However, for the C-I-B path, credibility can exert more influence on brand value by information cost saved in service category (0.352) than in manufacturing category $(0.2208)$. The deep reason is that since there is more uncertainty in service experience, easing anxiety and perceived risk before a deal is the key for brand as a signal. So, information problem is more critical to consumer' decisionmaking in-service category. A credible brand as a signal in this category can brings more value to consumers by largely solving the difficult problem of huge information asymmetry between consumers and sellers caused by the characters of service category, compared with manufacturing (Table 2).

\section{Conclusion and Advice for Firms}

\section{Conclusion}

In this paper we show how market processes information, how college students react to information that brands convey, which are rooted in consumer behavior. College students are sensitive to brand consistency, which underpins the brand credibility. And a credible signal brings brand value by facilitating perceived quality and contracting information cost. For the two paths, C-P-B outweighs C-I-B dramatically in both categories. And on C-I-B path, service category rests more on it than manufacturing category. But for C-P-B, both categories almost equal. So, it is information cost that mainly causes the difference of perceived brand value between manufacturing and services [27].

\section{Advice for firms}

Brand investment cannot be launched blindly. Firms should implement promotion activities or strategies that based on the principle of brand consistancy, especially for the service firms. For example, many firms build chain stores. It is a very good way to lift brand credibility. Chain stores with good reputation can provide uniform products or services with the same quality, price, tastes and so on, thus reducing consumers' information costs, increasing their recognition and appreciation of those brands, such as KFC, Home Inn.

No matter what category they are, all firms should intensify the cultivation of brands, especially for the firms whose targeted consumers are college students. Because college students attach much attention to brands. A credible brand can be an effective and efficient signal to bring much profits to a firm and become a part of competitiveness [28].

We can see from above analysis that the main difference of information asymmetry between service and manufacturing categories lies in information cost instead of perceived quality. So, the different effect of a credible brand on the form of brand value in the both categories mainly depend on the C-I-B path. Firms in service category should convey more clarification and conciseness of their service and products in their advertisement and promotion campaigns. Above all, C-P-B outweighs C-I-B dramatically in both categories in the formation of brand value. So, we can say that a credible brand mainly embodies products and service's good quality, which is the essence of a brand's credibility and its value. All firms should strictly control the management of their products' quality and do their best to improve every detail of their products and service, such as packaging, cleanness, humanization, to optimize consumers'percived experience [29,30].

\section{Improvement and further research}

This paper just studies the brand value based on investigation on college students. And we believe the universality of consumer behavior gives our research a foundation to further study from college students to typical consumers using more comprehensive database. Another is that the service and manufacturing categories are general, which provides the opportunity to subdivide the category to specific industries. Last but not least, further studies can focus on the difference of brand value for different groups, genders, age, technology level and so on.

\section{References}

1. George A Akerlof (1970) The Market for "Lemons": Quality Uncertainty and the Market Mechanism. The Quarterly Journal of Economics 84(3): 488-500.

2. Armen A Alchian (1950) Uncertainty, Evolution, and Economic Theory. Journal of Political Economy 58(3): 211-221.

3. Kenneth J Arrow (1998) What Has Economics to Say about Racial Discrimination? The Journal of Economic Perspectives 12(2): 91-100.

4. Friedrich A Hayek (1945) The Use of Knowledge in Society. The American Economic Review 35(4): 519-530

5. Sanford J Grossman, Joseph E (1976) Information and Competitive Price Systems. The American Economic Review 66(2): 246-253.

6. Joseph E Stiglitz (1979). Equilibrium in Product Markets with Imperfect Information. The American Economic Review 69(2): 339-345.

7. Joseph E Stiglitz (2000) The Contributions of the Economics of Information to Twentieth Century Economics. The Quarterly Journal of Economics 115(4): 1441-1478.

8. Tülin Erdem, Joffre Swait (1998) Brand Equity as a Signaling Phenomenon. Journal of Consumer Psychology 7(2): 131-157.

9. Richard P Bagozzi, Youjae Yi (1988) On the Evaluation of Structural Equation Models. Journal of The Academy of Marketing Science16(1): 74-94.

10. Birger Wemerfelt (1988) Umbrella branding as a signal of new product quality: An example of signaling by posting a bond. Rand Journal of Economics 19(3): 458-466.

11. Tülin Erdem, JoffreSwait (2004) Brand Credibility, Brand Consideration, and Choice. Journal of Consumer Research 31(1): 191-198.

12. Tülin Erdem, Joffre Swait, Ana Valenzuela (2006) Brands as Signals: A Cross-Country Validation Study. Journal of Marketing 70(1): 34-49.

13. Vithala R Rao, Manoj K Agarwal, Denise Dahlhoff (2004) How Is Manifest Branding Strategy Related to the Intangible Value of a Corporation? Journal of Marketing 68(4): 126-141.

14. E Calderon Monge, P Huerta Zavala (2015) Brand and Price: Key Signals when Opening a Franchise Outlet. Journal of Promotion Management 21: 416-431. 


\section{Annals of Social Sciences \& Management studies}

15. Y Strizhakova, RA Coulter, LL Price (2011) Branding in a global marketplace: The mediating effects of quality and self-identity brand signals. Intern J of Research in Marketing 28: 342-351.

16. Rob MA Nelissen, Marijn HC Meijers (2011) Social benefits of luxury brands as costly signals of wealth and status." Evolution and Human Behavior 32: 343-355.

17. M Rahman, M Rodríguez-Serrano, M Lambkin (2018) Brand management efficiency and firm value: An integrated resource based and signalling theory perspective. Industrial Marketing Management journal 72: 112-126.

18. Praveen R Nayyar (1990) Information Asymmetries: A Source of Competitive Advantage for Diversified Service Firms. Strategic Management Journal 11(7): 513-519.

19. Zhang Yali, LU Guizhi, JIN Tonglin, LI Sen, Jiang Huaibin, et al. (2018) The Effect of College Students 'Mobile Phone Addiction Tendency on Their Interpersonal Adaptability: The Intermediary Role of Alexithymia. Chinese Journal of Special Education 2: 21.

20. CUI Dan, LI Rui, CHEN Yan, MA Bingran, JIA Zimu, et al. (2018) An Evaluation of the Water Environmental Carrying Capacity Using Structural Equation Modeling: A Case Study of the Upstream Areas of Xiaoxia Bridge Section in Huangshui River Basin. Acta Scientiae Circumstantiae 39(2): 624-632.

21. Carol J Simon, Mary W Sullivan (1993) The Measurement and Determinants of Brand Equity: A Financial Approach. Marketing Science 12(1): 28-52.
22. Han Hui-lin, Zou Tong-qian, Zhuang Fei-peng (2017) Research on Function Paths of Corporate Brand Image on Purchase Intention: Based on China's Multi-national Enterprises. Academic journal of Central University of Finance and Economics. 8: 91-99.

23. Joseph E Stiglitz (2002) Information and the Change in the Paradigm in Economics. The American Economic Review 92(3): 460-501.

24. Joseph E Stiglitz (1985) Information and Economic Analysis: A Perspective. The Economic Journal 95: 21-41.

25. Joseph E Stiglitz (1989) Markets, Market Failures, and Development. The American Economic Review 79(2): 197-203.

26. John H Dunning (2009) Location and the Multinational Enterprise: John Dunning's Thoughts on Receiving the "Journal of International Business Studies" 2008 Decade Award. Journal of International Business Studies 40(1): 20-34.

27. Kenneth J Arrow (1963) Uncertainty and the Welfare Economics of Medical Care. The American Economic Review 53(5): 941-973.

28. Marc Fischer, Franziska Volckner, Henrik Sattler (2010) How Important Are Brands? A Cross-Category, Cross-Country Study. Journal of Marketing Research 47(5): 823-839.

29. R Mazali, J Rodrigues-Neto (2013) Dress to impress: Brands as status symbols. Games and Economic Behavior 82: 103-131.

30. Wang Chengrong, Wang Yujun (2014) Time-honored Brand Value Evaluation Model. Management Review 26(6).

This work is licensed under Creative Commons Attribution 4.0 License

DOI:10.19080/ASM.2019.04.555631

\section{Your next submission with Juniper Publishers} will reach you the below assets

- Quality Editorial service

- Swift Peer Review

- Reprints availability

- E-prints Service

- Manuscript Podcast for convenient understanding

- Global attainment for your research

- Manuscript accessibility in different formats

( Pdf, E-pub, Full Text, Audio)

- Unceasing customer service

Track the below URL for one-step submission https://juniperpublishers.com/online-submission.php 